Org Lett. 2018 August 17; 20(16): 4885-4887. doi:10.1021/acs.orglett.8b02030.

\title{
Synthesis of 5-Methylene-2-pyrrolones
}

\author{
Marco Paolo Jacinto\#, Patricio Pichling\#, and Marc M. Greenberg* \\ Department of Chemistry, Johns Hopkins University, 3400 North Charles Street, Baltimore, \\ Maryland 21218, United States \\ \# These authors contributed equally to this work.
}

\begin{abstract}
A facile, one-pot synthetic method for the synthesis of 5-methylene-2-pyrrolones (5MPs) from inexpensive furfuryl acetate is described. Bromine oxidation and trapping of the in situ generated 1,4-dicarbonyl compound by a primary amine provided the corresponding 5MPs in 50-69\% yield.
\end{abstract}

\section{Abstract}

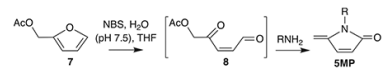

5-Methylene-2-pyrrolones (5MPs) have been detected in modified proteins following reaction with oxidatively damaged DNA and may have significant biochemical consequences. ${ }^{1-6}$ They have also been detected in reactions between amines and 2deoxyribose 5-phosphate under Maillard type reaction conditions. ${ }^{7}$ More recently, 5MPs have been shown to be useful alternatives to maleimides in bioconjugation reactions. ${ }^{8}$ 5MP conjugates offer some advantages over the respective maleimide adducts, including greater resistance to hydrolysis and ready release of the conjugated molecule under mild reaction conditions. The recently discovered utility of 5MPs increases their attractiveness in conjugation reactions. We wish to report a facile, inexpensive method for 5MP synthesis, which makes this family of molecules more accessible.

The most common method for 5MP synthesis proceeds through $3,{ }^{9}$ which is obtained from furfuryl alcohol (1, Scheme 1). ${ }^{1-3}$ Intermediate 2 is commercially available, but is costly ( $\$ 28.50 / \mathrm{g}$, Aldrich Chemical). Zhou and others report good to excellent 5MP yields following acidic hydrolysis of 3 . However, this proved difficult in our hands. ${ }^{8}$ While in search of an alternative method for 5MP synthesis, we were inspired by the work of Madder. 10-15 The Madder group has made extensive use of in situ generation and trapping (6) of 1,4dicarbonyl compounds (5) via bromine oxidation of furans (4) in aqueous conditions (Scheme 2). Various furan modified biopolymers have been conjugated using this strategy, as well as using a similar approach developed by Aso. ${ }^{16}$

*Corresponding Author: mgreenberg@jhu.edu.

Supporting Information

The Supporting Information is available free of charge on the ACS Publications website at DOI: 10.1021/acs.orglett.8b02030.

All experimental details and spectroscopic data for all new compounds (PDF)

The authors declare no competing financial interest. 
We envisaged executing a one-pot procedure involving $N$-bromosuccinimide (NBS) oxidation of inexpensive ( $\$ 1.20 / \mathrm{g}$, Aldrich Chemical) furfuryl acetate (7, Scheme 3). Trapping of the in situ generated 1,4-dicarbonyl (8) by a primary amine was expected to generate the hydrated 2-hydoxypyrrole (9), which would yield the corresponding 5MP upon sequential loss of water and acetic acid.

Suitable reaction conditions were explored using benzylamine $\left(\mathrm{BnNH}_{2}\right)$ as the nucleophile (Table 1). NBS oxidation (1.2 equiv) of 7 was carried out in THF at $0{ }^{\circ} \mathrm{C}$. Oxidation was complete in $1 \mathrm{~h}$, at which time benzylamine (1.2 equiv) was added and the reaction was continued and warmed to room temperature overnight. No product was isolated in the absence of $\mathrm{H}_{2} \mathrm{O}$, whereas the presence of $10 \%$ by volume provided 10 in $34 \%$ yield. However, more was not better in the case of $\mathrm{H}_{2} \mathrm{O}$, as the yields of 10 decreased to $27 \%$ and $21 \%$ when the solvent contained $25 \%$ and $50 \%$ water, respectively.

Initial attempts to buffer the reaction (entry 5, Table 1) suggested that the oxidation reaction proceeded, but 10 was obtained in low yield. We sought to balance the desire to increase buffering capacity and maintain reactant concentrations sufficient to ensure a reasonable reaction rate. The limited solubility of phosphate in the presence of cosolvent required that the aqueous content of the reaction be increased to $50 \%$ by volume (entry 6 , Table 1 ). This resulted in a 50\% yield of 10 . Using these buffer conditions, we then examined the effects of varying the number of equivalents of NBS and benzylamine $\left(\mathrm{BnNH}_{2}\right.$, Table 1). Increasing the number of equivalents of NBS to 2 and 4 resulted in drastically lower yields of 10 . Similarly, increasing the number of $\mathrm{BnNH}_{2}$ equivalents to 2 and 4 resulted in significant reductions in yields of 10 . We speculate that this is due to higher levels of bis- $\mathrm{BnNH}_{2}$ adducts of 8 (Scheme 3 ).

The reactions of amines with carbonyl groups are mechanistically complicated involving multiple acid-base equilibria. ${ }^{17}$ Consequently, we examined the effect of buffer and $\mathrm{pH}$ on the yield of 10 (Table 2). Using the optimum conditions obtained in phosphate buffer (PB, entry 6, Table 1), we carried out the reaction between furfuryl acetate (7) and $\mathrm{BnNH}_{2}$ in HEPES and MOPS at the same pH (7.5). Varying the buffer did not result in any improvement in the yield of 10 compared to what was obtained using phosphate buffer. Due to the possible delicate balance between rate-determining steps as a function of $\mathrm{pH}$, we carried out the reaction to form 10 at pH 6.0 (entry 3, Table 2) and pH 8.5 (entry 4, Table 2). ${ }^{17}$ However, both reaction conditions provided significantly lower yields of 10 than did the reaction at $\mathrm{pH} 7.5$.

The substrate scope of the reaction was examined using the optimized conditions at $\mathrm{pH} 7.5$ in phosphate buffer (Figure 1). Phosphate was chosen because none of the more expensive buffers provided better yields of 10 . The range in yields was rather narrow (50-69\%) despite the variation in $\mathrm{p} K_{\mathrm{a}}$ of the primary amine (e.g., aniline $\mathrm{p} K_{\mathrm{a}}=4.6$ for $11, n$-butylamine $\mathrm{p} K_{\mathrm{a}}=$ 10.78 for 13). The reaction was tolerant of incorporating an alkyne (12), which could be useful for potential click reactions. It even was possible to form the respective 5MP containing a free hydroxyl group when using ethanolamine (14). Although the isolated yields of 12 and 14 are lower than those recently reported, it is difficult to compare the methods directly because the previous strategy started from $\mathbf{3}$ (Scheme 1) ${ }^{8}$ In contrast, 
attempts to form the corresponding 5MP from 3-amino-1-hydroxypropane yielded a complicated mixture (not shown). However, the corresponding silyl ether (15) was compatible with the reaction conditions. The one-step 5MP formation was also compatible with esters $(\mathbf{1 6}, \mathbf{1 7})$, as well as a protected form of lysine (17). The latter is important because it suggests that the method could be useful for synthesizing peptides containing a 5methylene-2-pyrrolone (5MP), which would be useful in studying the biochemical effects of this unusual protein modification. ${ }^{6}$

Ultimately, the utility of some of the 5MPs will depend upon their stability, which varies widely depending upon the nitrogen substituent. For instance, $\mathbf{1 0}$ and $\mathbf{1 1}$ were stable for prolonged periods at $-20^{\circ} \mathrm{C}$ and for $1-2$ days at room temperature. Compounds 13 and 1517 were stable for more than 1 week at $-20{ }^{\circ} \mathrm{C}$ but exhibited limited decomposition over longer periods of time. 5MPs 12 and 14 were the most difficult to handle. The ethanolamine adduct (14) decomposed within 1 day at $-20^{\circ} \mathrm{C}$. The propargylamine lactam (12) was even more unstable. It decomposed at $-20{ }^{\circ} \mathrm{C}$ within hours of isolation.

In summary, we report a one-step synthesis of 5-methylene-2-pyrrolones (5MPs) from an inexpensive starting material, furfuryl acetate. The method is tolerant of a number of functional groups. When combined with the recent report describing the use of 5MPs in bioconjugation, this method should prove useful in a variety of applications. ${ }^{8}$

\section{Supplementary Material}

Refer to Web version on PubMed Central for supplementary material.

\section{ACKNOWLEDGMENTS}

We are grateful for generous financial support from the National Institute of General Medical Science (GM-063028). P.P. thanks Johns Hopkins University for a Greer Fellowship.

\section{REFERENCES}

(1). Aso M; Kondo M; Suemune H; Hecht SM J. Am. Chem. Soc 1999, 121, 9023-9033.

(2). Usui K; Aso M; Fukuda M; Suemune HJ Org. Chem 2008, 73, 241-248.

(3). Aso M; Usui K; Fukuda M; Kakihara Y; Goromaru T; Suemune H Org. Lett 2006, 8, 3183-3186. [PubMed: 16836361]

(4). Jacobs AC; Kreller CR; Greenberg MM Biochemistry 2011, 50, 136-143. [PubMed: 21155533]

(5). Stevens AJ; Guan L; Bebenek K; Kunkel TA; Greenberg MM Biochemistry 2013, 52, 975-983. [PubMed: 23330920]

(6). Zhou C; Sczepanski JT; Greenberg MM J. Am. Chem. Soc 2013, 135, 5274-5277. [PubMed: 23531104]

(7). Munanairi A; O’Banion SK; Gamble R; Breuer E; Harris AW; Sandwick RK Carbohydr. Res 2007, 342, 2575-2592. [PubMed: 17850774]

(8). Zhang Y; Zhou X; Xie Y; Greenberg MM; Xi Z; Zhou CJ Am. Chem. Soc 2017, 139, 6146-6151.

(9). Edwards WR; Mitchell MJ J. Am. Chem. Soc 1954, 76, 5150-5152.

(10). Halila S; Velasco T; De Clercq P; Madder A Chem. Commun 2005, 936-938.

(11). Jawalekar AM; Op de Beeck M; van Delft FL; Madder A Chem. Commun 2011, 47, 2796-2798.

(12). Op de Beeck M; Madder AJ Am. Chem. Soc 2011, 133, 796-807.

(13). Carrette LLG; Morii T; Madder A Bioconjugate Chem 2013, 24, 2008-2014.

Org Lett. Author manuscript; available in PMC 2019 August 17. 
(14). Vannecke W; Ampe C; Van Troys M; Beltramo M; Madder A ACS Chem. Biol 2017, 12, $2191-$ 2200. [PubMed: 28714670]

(15). Carrette LLG; Gyssels E; De Laet N; Madder A Chem. Commun 2016, 52, 1539-1554.

(16). Yang B; Jinnouchi A; Usui K; Katayama T; Fujii M; Suemune H; Aso M Bioconjugate Chem 2015, 26, 1830-1838.

(17). Jencks WP Catalysis in Chemistry and Enzymology; McGraw-Hill: New York, 1969. 

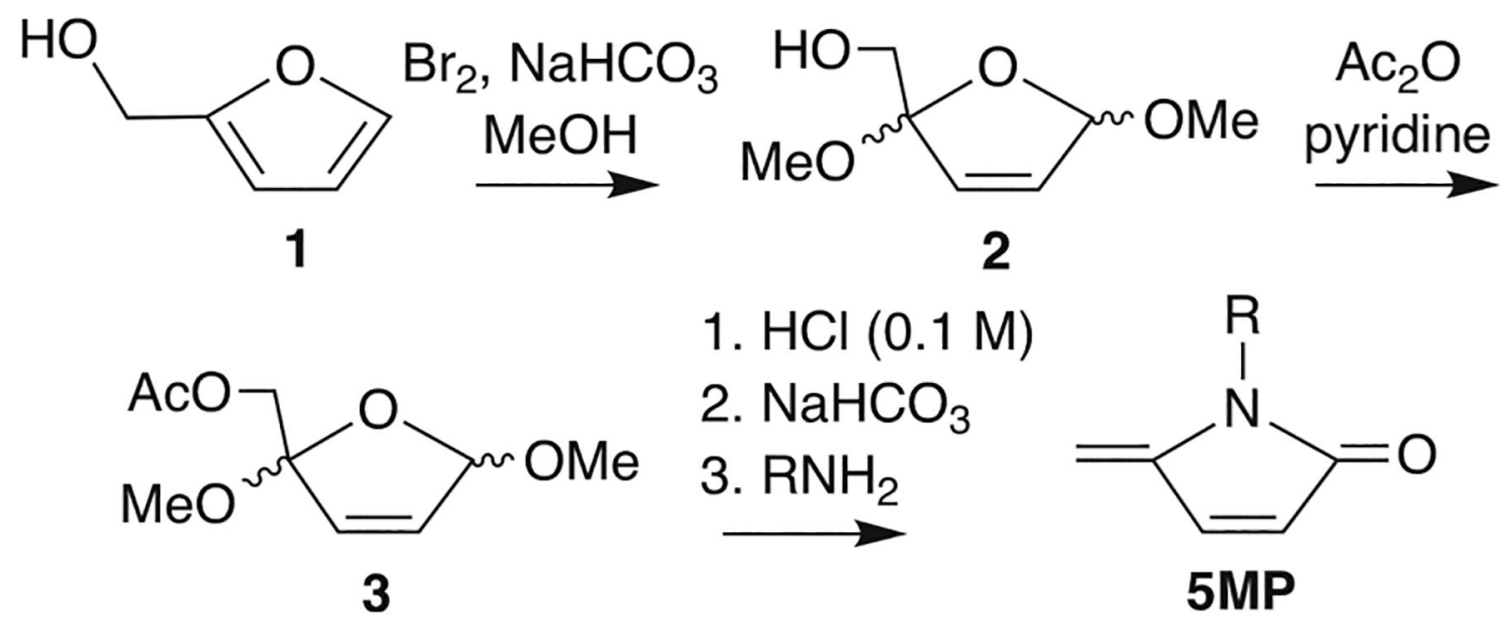

Scheme 1.

Existing Method for 5-Methylene-2-pyrrolone (5MP) Synthesis 

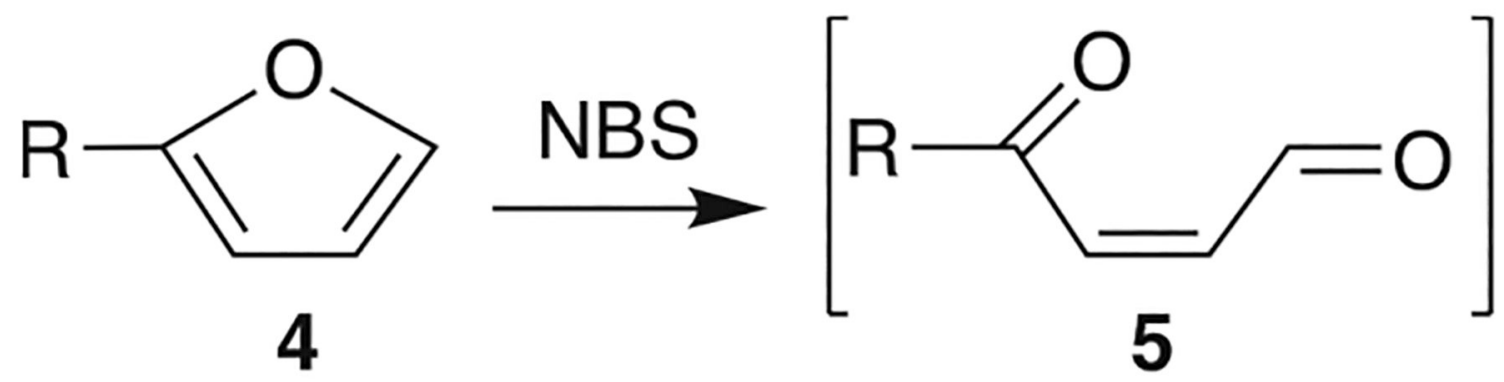

1. $\mathrm{RNH}_{2}$
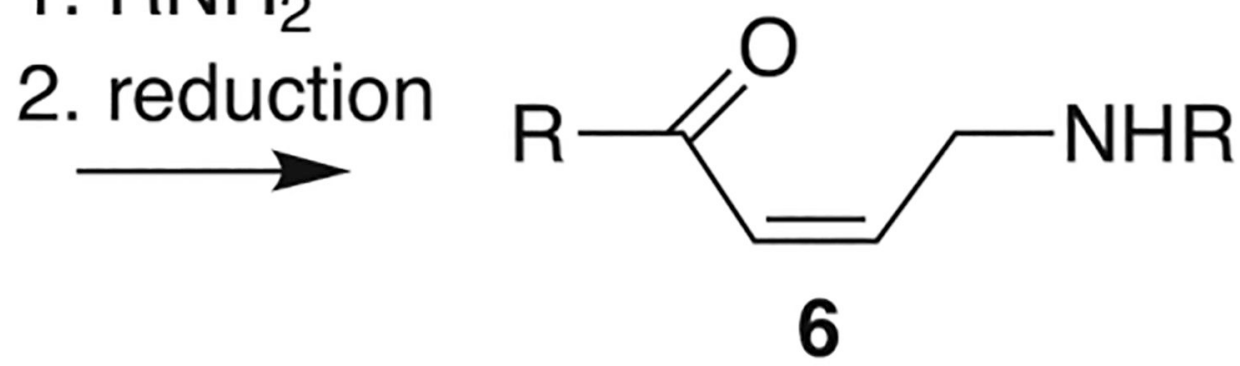

Scheme 2.

Madder Method for in Situ Generation and Trapping of 1,4-Dicarbonyl Compounds 

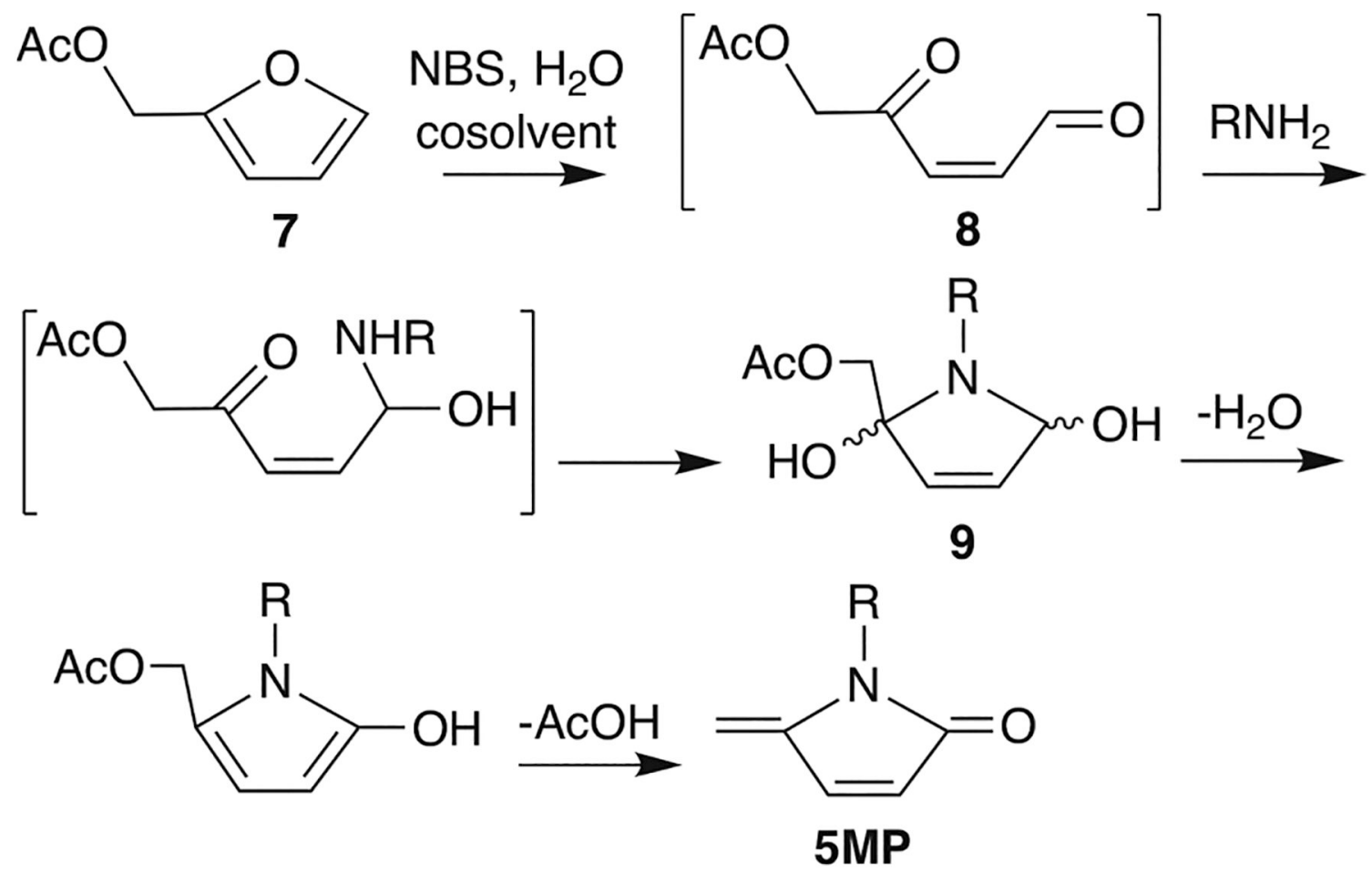

Scheme 3.

One-Pot Formation of 5-Methylene-2-pyrrolones (5MPs) 


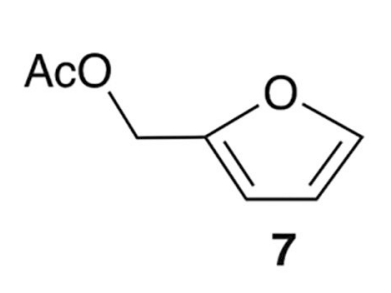

1. NBS (1.2 equiv), $0^{\circ} \mathrm{C}$

2. $\mathrm{RNH}_{2}$ (1.2 equiv), $0-25^{\circ} \mathrm{C}$

1:1 THF/0.25 M phosphate $\mathrm{pH} 7.5$, overnight<smiles>[R]N1C(=C)C=CC1=O</smiles>

$5 \mathrm{MP}$

(10-17)<smiles>C=C1C=CC(=O)N1Br</smiles><smiles>C=C1C=CC(=O)N1Pc1ccccc1</smiles><smiles>C#CCN1C(=C)C=CC1=O</smiles>

$10,50 \%$

$11,50 \%$

$12,54 \%$

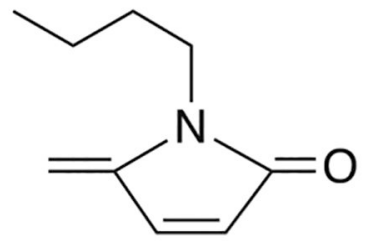

$13,54 \%$

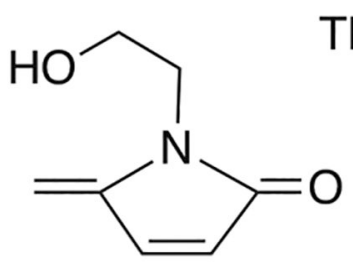

$14,53 \%$
TBSO<smiles>C=C1C=CC(=O)N1CCCI</smiles>

$15,60 \%$<smiles>C=C1C=CC(=O)N1CCC(=O)OCCC</smiles>

$16,57 \%$<smiles>C=C1C=CC(=O)N1CCCC[C@H](NC(C)=O)C(=O)OC</smiles>

$17,69 \%$

Figure 1.

Substrate scope. Reaction conditions: NBS (1.2 mmol) was added to a solution $(20 \mathrm{~mL}, 1: 1$ $\mathrm{THF} / 0.125 \mathrm{M} \mathrm{PB} \mathrm{pH} 7.5)$ of $7(1 \mathrm{mmol})$ at $0{ }^{\circ} \mathrm{C}$ and stirred for $1 \mathrm{~h}$, then $\mathrm{RNH}_{2}(1.2 \mathrm{mmol})$ was added, and the reaction was allowed to warm to room temperature overnight. Yield refers to isolated product. 
Table 1.

Reaction Condition Optimization for 5MP (10) Formation Using Benzylamine ${ }^{a}$



${ }^{a}$ Reaction conditions: NBS $(1.2-4 \mathrm{mmol})$ was added to a solution $(20 \mathrm{~mL})$ of $7(1 \mathrm{mmol})$ at $0{ }^{\circ} \mathrm{C}$ and stirred for $1 \mathrm{~h}$, then $\mathrm{BnNH} 2(1.2-4 \mathrm{mmol})$ was added, and the reaction was allowed to warm to room temperature overnight. Solvent ratios are $\mathrm{v} / \mathrm{v}$.

$b_{\text {Yield refers to isolated product. }}$

${ }^{c} \mathrm{~PB}=$ phosphate buffer $(\mathrm{pH} 7.5)$. [Buffer] is that present in the reaction. 
Table 2.

Buffer and pH Effect on 5MP (10) Yield $^{a}$

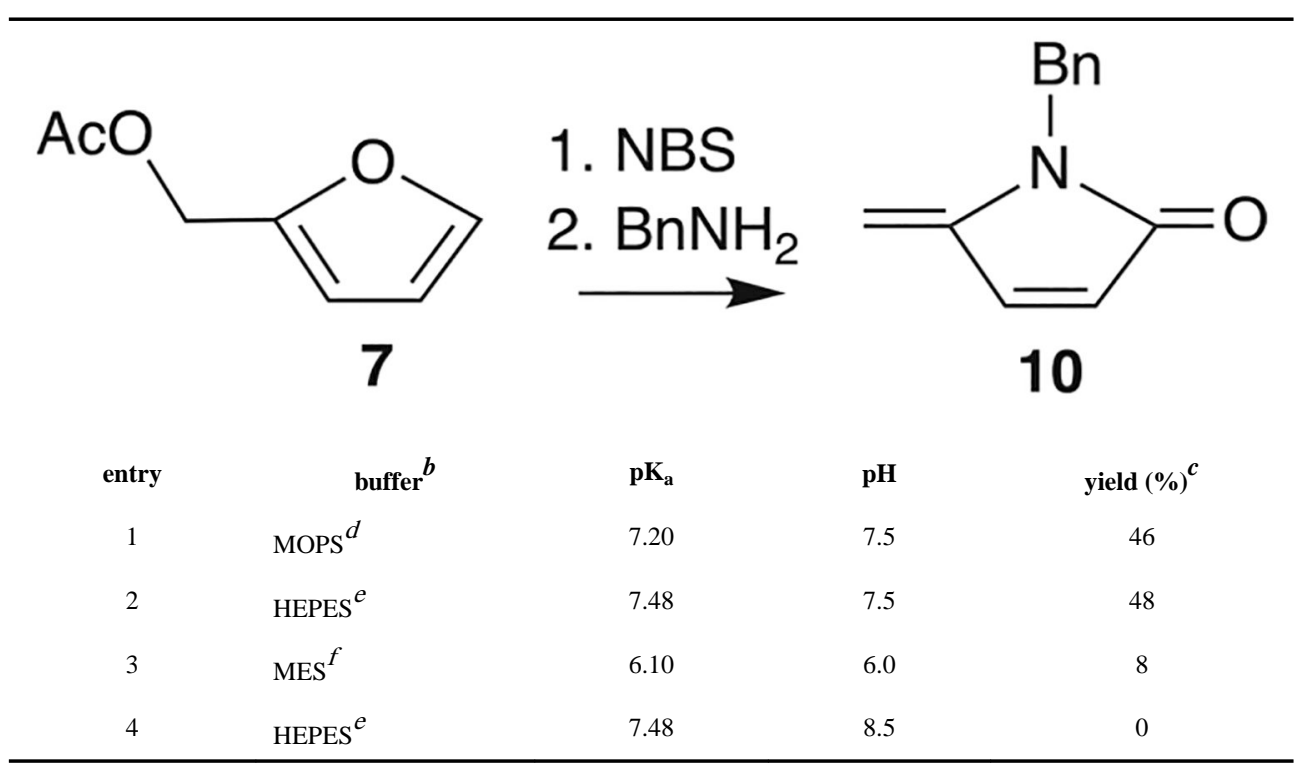

${ }^{a}$ Reaction conditions: NBS $(1.2 \mathrm{mmol})$ was added to a solution $(20 \mathrm{~mL}, 1: 1 \mathrm{THF} / \mathrm{buffer})$ of $7(1 \mathrm{mmol})$ at $0{ }^{\circ} \mathrm{C}$ and stirred for $1 \mathrm{~h}$, then $\mathrm{BnNH}_{2}(1.2$ $\mathrm{mmol}$ ) was added, and the reaction was allowed to warm to room temperature overnight.

$b_{[\text {Buffer }]}=0.125 \mathrm{M}$ in the reaction.

Isolated yield.

${ }^{d}$ MOPS, 3-(N-morpholino)propanesulfonic acid.

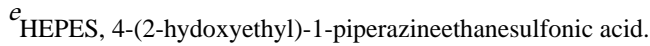

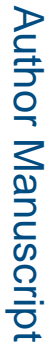

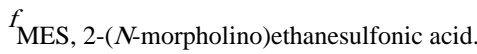

